\title{
DOES ANONYMITY MATTER? A DISCOURSAL STUDY OF GENDER RECOGNITON ON ARABIC FACEBOOK COMMENTS
}

\author{
Nashwan Mustafa Al-Sa'ati \\ College of Arts, University of Mosul, Iraq. \\ sidranash@yahoo.com
}

Manuscript received 23 August 2019

Manuscript accepted 5 Nov 2019

*Corressponding author

https://doi.org/10.33736/ils.1771.2019

\begin{abstract}
This study considered the recognition of persons' gender through the differences of the discoursal features and stylistic choices of their Arabic Facebook comments. Three hundred comments on different topics were collected from same-/cross-sex interactions of friends, acquaintances and relatives having similar educational and social backgrounds and with an age range 20-50. Some research questions were raised as to whether males and females differed in terms of the discoursal features of their comments as well as the ability to recognize the person's gender on the basis of these features. Accordingly, some hypotheses were formulated, viz. males' and females' comments involved distinguished gendered discoursal features and styles, females behaved in line with maintenance roles while males behaved in line with task- oriented roles, and the persons' gender could be predicted through applying the gendered features they had. The study came up with various conclusions that, to some extent, confirmed the hypotheses stated.
\end{abstract}

Keywords: Discourse analysis, gender recognition, gender differences, facebook, arabic comments, anonymity

\section{Introduction}

Gender is a primary category for understanding the world around us when we enter into any conversation. Based on visible cues, we recognize that each participant we are interacting with is a man or a woman. Immediately, then stereotypes come into play which affect the impression we form (Weatherall, 2005). However, Arize (1996:20) argues that gender is much more complex than the acquisition of 
internalized stable patterns of behavior. We must, he adds, account for the confusion of gender with social roles and status and for the fact that in particular contexts a man or a woman may display either feminine or masculine behavior. People do not behave consistently in different situations. Hence, there are multiple aspects to the self, and people display them differently depending on the participants in an interaction or the demands of the situational context (ibid, 1996:20). Gender, then, is not simply a matter of sex but also its consequences affect the social, practical and political life in the community.

\section{Research Problem}

Computer-mediated communication (CMC) systems become commonplace in our society, and researchers are increasingly investigating how these technologies impact our lives. Among the numerous research topics, one interesting issue concerns the recognition of gender.

This research discusses the differences in styles of participation that exist between males and females which can, in turn, give information about the person's gender and identity since the differences between males and females may lead sometimes to misunderstanding and cause a problem especially with no physical cues or body language available.

Thus, the study aims at understanding how gender interacts with communicative style to affect participation, by identifying the differences in the gender discoursal features of males' and females' Iraqi Arabic comments on Facebook, and by figuring out the gender of the user through the identified discoursal features.

The significance of this study lies in the fact that it is an addition to the studies about gender differences in Internet language interaction. Users on the Internet can figure out the gender of the anonymous person chatting with through certain discoursal and stylistic features that one gender uses more than the other.

\section{Literature Review}

Research studies have noted the relationship between gender and language in computer-mediated-communication. Smith and Balka (as cited in Herring, 2000) found that participation by both males and females is almost equal in an anonymous computer system. This has made Hraway (as cited in Fischer, 2011, p. 53) believe that sexual inequalities would dissolve on the Internet. This resulted in the claim raised by Postmes and Spears (as cited in Berchmeir et al., 2011) that communication, with the lack of physical cues and equal status and opportunities on the Internet, would be free from sex stereotypes. A fact that was confirmed by Herring (2000) who argues that the absence of physical cues, as to message sender's identity, removes all the information of gender, race social class, etc. (Crowston \& Kammerer, 2010) for equalitarian gendered features.

However, Herring (as cited in Savicki et al., 2006) points out that differences between genders existed and can to a large extent be the same as differences in

Does Anonymity Matter? A Discoursal Study of Gender Recogniton on Arabic Facebook Comments 
face-to-face communication. She also noticed that there are some obvious differences in email messages to the extent that one can judge whether the sender is a female or a male. In a study, Bruckman (as cited in Herring, 2003) found that females tend to receive more responses to their messages than males.

Moreover, a case study analyzed employees' attitudes toward, and experiences with, an organizational electronic mail system. Results revealed that females perceived e-mail to be easier to use, more efficient (active), and more effective than males. (Savicki et al., 2006).

Another study revealed some relationships between gender and satisfaction with CMC. As a result, females viewed CMC more favorably than males. Despite that, studies related to gender differences have shown different results (Ahmad \& Ahmad, 2018; Herring \& Stoerger, 2013; Kapidzic \& Herring, 2011; Li \& Kirkup, 2018; Lin \& Wang, 2019; Miller \& Durndell, 2004; Sambasivan, 2019; Sussman \& Tyson, 2000)

\section{Research Questions and Hypotheses}

In this study, the following research questions are addressed:

1. To what extent do males and females differ in terms of the discoursal and stylistic features of their comments on Facebook?

2. Can the person's gender and identity be identified on the basis of analyzing these features?

The study hypothesizes that:

1. Males and Females' comments involve distinguished gender discoursal features and styles.

2. The persons' gender and identity are predicted through the gender features they experience in their interaction (comments) with others.

\section{Methodology}

The data were collected during the year 2016- 2017 from friends', acquaintances' and relatives' comments on Facebook. Three hundred comments on different topics were collected from three sorts of interaction with each sort having an equal quantity of comments, 100 . These three sorts of interactions include same-sex, i.e. male-male and female-female, and cross-sex interaction, namely male-female interaction. The comments had been taken from participants having similar educational and social background with an age range 20-50.

The analysis methods are:

i. Extracting certain linguistic and discoursal features from the data. These features include the type of vocabulary or lexical words used, the type of syntactic structures and the stylistic and rhetorical features.

ii. Comparing the three sorts of interaction as far as the previous linguistic and discoursal features are concerned to figure out the gender differences and 
identify the person's gender and identity on the basis of these features, as a result.

iii. Presenting tables for the frequencies of adopting each feature by males or females through the three sorts of interaction

iv. Designing a test for recognizing gender anonymity. The test involves asking some researcher's friends to send some comments from Facebook to the researcher without showing the gender in advance so as to keep the gender of the persons writing the comments unknown. Depending on the cues discovered in the study conclusions, these comments have been analyzed to test whether or not we can differentiate the gender of the person.

v. Asking back, then, these researcher's friends to reveal the gender to know whether or not we have been accurate in determining the gender of the persons responsible for these comments.

\section{Results and Discussion}

The first part of the results is related to lexical differences based on several key patterns of use.

\section{Lexical Differences}

\section{Colour Words}

Some different colour vocabularies between females and males were observed. Let us consider the following excerpt between two males talking about the colour of the tie they chose to wear at their graduation party. Speaker $A$ is asking to make sure that they chose the purple colour. B answers him with a positive approval:

A: / rah nilbas ribæ:t banafsad3i: Jabæ:b/

(Are we going to wear a purple tie, guys?)

B: / ?e: banafsad3i: ?ittafaqnæ:/

(Yes, purple. It's a deal)

Later, a girl interacts commenting:

C: /læ: darad3at hæ:đa illo:n ?ismo: ka[mi:r mo: banafsad3i:/

(No, the shade of this colour is cashmere not purple)

The male friends agreed immediately on the colour while the female friend considered it to be another shade of the colour and gave it a specific name. The previous extract, then, indicates that females have a more specific sense for colours than males do.

\section{Empty (Neutral) Adjective}

Empty adjectives are used to soften sentences by adding a more intimate and friendly sense to them. In a female-female interaction, a female posted a picture of her daughter and got the following comments as a result:

Does Anonymity Matter? A Discoursal Study of Gender Recogniton on Arabic Facebook Comments 
B: / Jgad hilwa ?alla jitfadha/

(How beautiful she is! God bless her)

C: / kullij kju:t habi:bti/

(So cute my love)

A group of empty adjectives were restricted to females only, viz.

/kju:t/ (cute), /ræ:?i؟a/ (elegant), /d3ami:I/ (handsome), /qadi:ra/ (good) and /ræ:qi:/ (elegant) while /mubdiৎ/ ( creative), /mutamjjiz/ (distinct), /rahi:b/ (incredible), /Sadi:m/ (great), and /raw̧a/ (amazing ) were restricted to males, though the adjectives/ Sazi:za/ ( precious), /d3ami:la/ (beautiful) and/hilwa/ (nice) were used by both males and females.

\section{Intensifiers}

Another lexical difference between males and females is the frequent use of intensifiers by females. That is why, in the data we could hardly find examples where males use intensifiers in their comments. Let us look at the following example:

A: / finu: ra?jukum bhæ:đa iffaxis /

(What is your opinion about this person?)

B: /?istiGræ:di: hwæ:ja/

(He is showing off too much)

Through the above- example, the first-person, A, is asking about a specific newly known doctor. He attached his question with a photo of the person. In reaction, $\mathrm{B}$ comments on the post giving his opinion about that person by saying that he shows off too much (in the sense that instead of saying useful things in his lecture, the doctor just shows off). Thus, the person uses the intensifier /hwæ:ja/ (too much) to show how much the person is showing off.

\section{Hedges}

The use of this strategy involves the use of mitigating words by the speaker to indicate that he/she is uncertain about what to say. On the other hand, the speaker can be certain about what he is about to say but he/she uses hedges so as not to impose the truth (e.g. he is kinda short). Sometimes it is used as a strategy for showing politeness.

Let us look at the following example between two females talking about a photo of them taken together and one of them is asking whether or not they remember the day it was taken:

A: / titðakkaru:n hæ:ða iljo:m/

(Do you remember this day?)

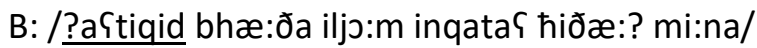

(I think it is the day when Mena's shoes cut off).

The second speaker is not sure of the day. That is why she starts with L?aStiqid/ ( I think) as a guess by her. 


\section{Vulgar Words}

In their comments through the data collected, males resort to vulgar words. The use of vulgar words is expressed in calling people by animal names which can be rude if the person actually has the intention of offending the person talking to. This is clearly shown in the following excerpt:
A: /miftæ:qulkum ћabæ:jib galbi ?itmanne:tkum wijjæ:ja/
(I miss you whole-hearted guys. I wish you are with me).
B: / miftæ:qlak talib/
(I miss you, $\underline{\text { dog) }}$

In the above excerpt, a male posts about his trip abroad writing to his friends that he missed them and wishing they are with him. Commenting back, B writes that he misses him too calling him /tfalib/ (dog). Vulgar words can be offensive when reading comments on public pages. However, males don't realize that they use a lot of inappropriate words in their comments especially when talking with their samesex partners.

In contrast, females in their cross-interaction hardly use this type of words due to the fact that they are judged by the society more than males. They need to know what they are typing and what the consequences of it; they can't write or type anything that can judge a female by her comments. However, females use these words more frequently with females than with males though it also depends on how close their relationship is.

\section{Emphatic Expressions}

An emphatic expression is one that is said to indicate the importance of the idea being introduced or having strong feelings towards what is said. Let us consider the following excerpt:
A: / minu: jid3i: nru: $\hbar$ ma\{rad ilkutub/
(Who wants to come to the book fair?)
B: /?aki:d ?ad3i:/
(I will for sure (definitely) come)
C: /? ?aki:d nJæ:rik/
(I will for sure (definitely) participate)

Both $B$ and $C$ are willing to participate in the book fair and they assure their answers with the emphatic expression /? aki:d/ (for sure (definitely)). In addition, one can notice that they are supportive to their friends through using these emphatic expressions.

In fact, females use emphatic expressions most of the time to show their feelings as well as to express agreement with the person being talked to. They do not argue a lot as males do, so they are of supportive nature. Some examples of the emphatic expressions include /fiৎlan/ (really), L?e: walla/ ( I swear).

Emphatic expressions are also so clear with cross-sex dyads. This is clearly shown in the following excerpt where $A$, a male, is talking about his trip to Malaysia especially when he tried parachuting. One of his female friends, B, who was with 
him during his trip, posts her comment to emphasize what he said and express her same feeling about the experience:

A: /?ittad3riba hulwa wfuৎu:r ittajaræ:n kæ:n jixabbil/

(The experience was nice, and the feeling of flying was incredible)

B: /fiqlan Juqu:r ittajaræ:n jixabbil/

(It was really an incredible feeling)

\section{Syntactic Structures}

Males and females use some different syntactic structures in posting their comments:

\section{Tag and Direct Questions}

Holmes (2006) points out that in using tag questions, the speaker assets something and asks for the listener's response. It is used to get confirmation about certain information; tag questions may also express uncertainty, or they may function as facilitative or positive politeness devices.

Let us consider the following excerpt between a male and a female friend:

A: /mnawri:n ?iћna bissu:ra/

(We look nice in the photo).

B: /?aJu: ?æ:ni: mæ:ku: bas læ: ?æ:ni: dæ:?asћab issu:ra mu: (?)/

(I am not shown in the photo, was I the one who took it, aren't I?)

In the first comment, $A$ is talking about a photo they took together in the past. The girl, B, is asking about herself in the photo wondering if she was the one who was in the photo. She was young at that time so she can't remember and is not sure. That is why she uses a tag question to ask for affirmation by anyone against her claim.

Furthermore, females may share their opinion by raising direct questions. This is due to the fact that sometimes they do not have the courage to say what they want directly or they want to save each other's face by hiding what is required with a question. This is shown in the following excerpt where a male posts a picture with his friends at the college including $B$, his female friend, and gets a direct question by his $B$ friend as a result:

B: / le:[ mnazzil hæ:j issu:ra (?) ?æ:ni: matæ:ISa hilwa/

(Why did you post this photo? I don't look beautiful)

Since she doesn't look beautiful in the photo, B, asks a question about the reason behind posting the photo by her friend, instead of saying directly "You shouldn't post the photo" (otherwise she would be considered impolite).

\section{Imperative}

Imperative is one of the grammatical structures that is used by males more frequently. This is due to the fact that males are more direct in their speech, while females feel that they do not have the right to tell others what to do. So, they try to soften their speech when they want someone to do something.

Does Anonymity Matter? A Discoursal Study of Gender Recogniton on Arabic Facebook Comments 
Let us consider the following extract between three males staying in a dorm:

A: /?ilhajæ:t do:d3a/

(Life is boring).

B: /? iqra lil?imtiћæ:n ?aћsan mæ:titfalsaf/

(Read for your exam instead of wasting your time)

C: /d3i:bli: ?akil wjæ:k min tid3i:/

(Bring me some food with you, when you come)

In the above-mentioned extract, the first-person complains about how boring life is. Instead of being supportive emotionally like females, his male friends just ignore his claim and start telling him what to do (since he is out while his friends are in the dorm studying for the exam). Hence, B asks him to start reading instead of complaining while $C$ asks him to bring with him some food while he is on his way to the dorm.

\section{Rhetorical Features}

Sarcasm

In sarcasm not only using harsh words that counts but most of the time mock and making fun of others or saying things that are the opposite to what is actually happening also count (cf. Herring, S. (1995)).

This is shown in the following example between two males talking about marriage where no bad or taboo words used:

A: / rah ?atzawwad3/

(I am getting married)

B: / jid3Salhæ: xæ:timat il?aћzæ:n ?axu:ja/

(My condolences to you, my brother)

A, the first speaker, posts that he is getting married and it is not like $100 \%$ true. This is clear through the comment he gets from B who is giving him condolences, which is, in turn, a kind of sarcasm since getting married is part of having happy news.

\section{Flaming}

Flaming is another term that can be, to some extent, similar to sarcasm but it is more direct and offensive. Some linguists describe it as "abuse" which is special for the online world. Males are less concerned about other's positive face; so, for them it is more about saying what they want directly whether it is harsh or offensive (Herring, 1996: 126).

Since the data concern comments from friends, acquaintances and relatives, flaming is not widespread. Let us look at the following example taken from a malefemale interaction where $A$, the female is talking about a childhood picture:

A: / Ju:f ræ:s ?aћmad JaSra mkaffif hhhhh/

(Look at Ahmad's head. His hair looks so thick hhhhh)

The girl is making fun of one of the boys in an old photo of his childhood. The guy is one of her relatives and through the photo, one realizes that she is older than 
him which makes it possible to write such a comment. She talks about his hair, but still one can consider the comment to be a joke between relatives especially when she adds the laugh at the end of the sentence to soften the meaning of the sentence from flaming into a joke. We realize that the guy also takes it as a joke when he replies with:

\section{B: / ?aћla min Jąrits /}

(My hair is more beautiful than yours)

He takes it as it is, a joke from a relative, and he does not flame back or say any bad word.

\section{Repetition of Letters}

As the title indicates, this strategy includes repeating a certain letter in a word several times to emphasize its intended meaning. It could refer to positive things; it comes sometimes as an exaggeration to emphasize feelings and a wish for something.

Let us look at the following example between two females talking about their own photo eating out:
B: / jJahi he:e:e:e:I/
(It's sooo delicious)
C: / twannasnæ: w?akalna ko:o: ::ma/
(We had so much fun and ate alooot)
D: / ?æ:ni ham ?ari:i:i:d/
(I waaant that too)

The girls are talking about their meeting out and eating in a restaurant. B is one of the girls talking about how delicious the food is using /he:e:e:e:l/ (sooo). Speaker $C$ as well repeats some letters of the word /kJ:o:J:ma/ ( alooot) to indicate that they ate more than any time. As a response, speaker $\mathrm{D}$ replies with /?ari:i:i:d/ (I waaant) to express her desire to be with them and probably also eat a lot of food since she wasn't with them.

\section{Exaggeration}

Exaggeration is a rhetorical device used to magnify things or to make them more important. It is also used to refer to people to make people seem better or worse than what they really are in reality. This is clearly shown in the following extract:

A: / talaba min matæ:Sim ittabarruS lil؟mæ:I biwad3bæ:t ?akil fakæ:n irrad min kubra matæ:Yim tastad3i:b litalabihi/

( He asked restaurants to donate some meals for workers and he got donation from the biggest restaurants in the area)

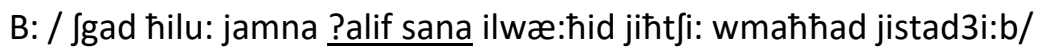

(That's beautiful; in our country if you talk thousands of years, no

one will respond)

The first female, A, posts about a male who asks restaurant owners to donate for helping workers and how big restaurant interacted with him to afford meals for the workers. In response, female $B$, reflects that this would be impossible in her 
country, people will talk for thousands of years and still no one would answer. She uses /?alif sana/ (thousands of years) as an exaggerated expression of showing how the situation is bad in her country, since no one actually responds during thousands of years.

Despite the common belief that the Internet will produce greater egalitarian communication, this research has proved that this is commonly not the case. The findings generally have indicated that on Arabic Facebook comments, people cannot liberate themselves from their gendered identities. The study reveals that a number of gender differences, expressed in the discoursal and stylistic features, are found. The results also reflects the characteristics of the informal context.

The findings suggest that sometimes participants gender- switch online. There has been some insight into the sort of people who gender- switch which suggests that they are predominantly males. The possible explanations for genderswitch is that males can experience some of the power that comes from being a man; they have a great deal of control; the absence of the physical body (the anonymous nature of the Internet) makes it possible for males to gender- switch.

The overal findings at in this study were tabulated and shown in the following tables:

Table 1

Frequency of lexical differences of males and females

\begin{tabular}{lccc}
\hline \multicolumn{1}{c}{ Lexical Differences } & Male-Male & $\begin{array}{c}\text { Female- } \\
\text { Female }\end{array}$ & Male-Female \\
\hline Colour words & 0 & 0 & 2 \\
Empty (Neutral) Adjective & 12 & 10 & 10 \\
Intensifiers & 2 & 6 & 6 \\
Hedges & 0 & 4 & 6 \\
Vulgar words & 5 & 1 & 1 \\
Emphatic expressions & 2 & 10 & 13 \\
\hline
\end{tabular}

Table 2

Frequency of Syntactic Differences of Males and Females

\begin{tabular}{lccc}
\hline \multicolumn{1}{c}{ Syntactic Structures } & Male-male & Female-Female & Male-Female \\
\hline Tag \& Direct Questions & 0 & 5 & 5 \\
Imperative & 6 & 3 & 3 \\
\hline
\end{tabular}

Does Anonymity Matter? A Discoursal Study of Gender Recogniton on Arabic Facebook Comments 
Table 3

Frequency of Rhetorical Differences of Males and Females

\begin{tabular}{lccc}
\hline \multicolumn{1}{c}{ Rhetorical Features } & Male-Male & Female-Female & Male-Female \\
\hline Sarcasm & 10 & 0 & 4 \\
Flaming & 12 & 2 & 5 \\
Repetition of Letters & 2 & 12 & 5 \\
Exaggeration & 3 & 13 & 3 \\
\hline
\end{tabular}

By looking at the strategies explored, the tables show that males and females differ in the way they communicate and the way they attempt to influence others. Females tend to have more expressive, cooperative, and polite communication characteristics, while males show more aggressive, assertive, direct, and powerful communication traits. Hence, as far as communication styles are concerned, the tables reflect that while males are more goal and task-oriented, females tend to be more people and relationship-oriented. It is no coincidence that these behaviors and values are also present in everyday discourse.

As in face-to-face communication, the findings indicate that females tend to use language that is powerless. For instance, it is found that females are least likely to argue. Their communication is more supportive. So, they act in reactive rather than proactive ways. Furthermore, females engage in interactivity and rely on the opinion of others to help construct their own knowledge, in the sense that females' messages are more emphatic, mention themselves and their families. They show more personal orientation in their language.

In contrast, males are found to be authoritatively oriented and this orientation is evidenced through language expressions. Comments by males were found to be more confrontational, autonomous, certain, arrogant and controlled. Males use coarser, somehow more abusive language and strong assertions. Males' postings, more than females, use humour and/or sarcasm; they seem to be attempting to establish dominance. They call out more answers during their interaction.

For recognizing gender anonymity, we asked the people, after finishing the whole designed test, who sent us the comments of the test to reveal the gender of the persons commenting; as a result, out of 30 comments, twenty-five ones were perfectly predicted, a point which shows a good confirmation of our study findings in relation to gender differences in Facebook interaction. Let us look at some truly and some wrongly predicted gendered comments.

A. Truly predicted gendered comments:

1. /tara mati:n sawwa tæ:k ?ilnæ: Yalamu:d jgillinna ?anu: huwwa yabi: mu: ?iћnæ:/

(Mateen tagged us to tell us he is stupid not we)

Does Anonymity Matter? A Discoursal Study of Gender Recogniton on Arabic Facebook Comments 
It is assumed that it is a male comment. This is due to the fact that the comment involves the word /yabi:/ (stupid), a cursing word which is used more frequently by males; Besides, the person uses flaming against one of his friends when he calls him /yabi: / (stupid).

2. /?abadaaaa mu: ?i†næ: iljo:m bas ?aktibilkum kummintæ:t li?an iljo:m binnisba ?ilijja Sutla/

(Those are not we at all, today I will just write you comments, it's like a holiday for me)

The assumption is that it is a female's comment. This is due to the fact that the person uses repetition of letters with the word /?abadaaaa/ (never).

3. / hhhhhh lati:f ilmuræ:qib ilwæ:gif 乌ale:na iljo:m baৎid wakit mu: hassa ?awazziৎ il?as?ila/

(The invigilator today was cute. He was saying I won't give the questions).

It is female's comment. This is so because the person uses /lati:f/ (cute), an empty adjective used by females more frequently, as well as using the repetition of letters between each of the two sentences.

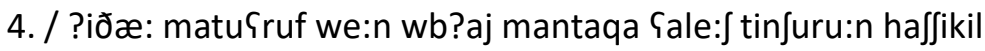
xabar wtilYabu:n b?aSsæ:b innæ:s/

(If you don't know where and in what place, why do you post it, you are playing with people's feelings)

The person in this comment is directly flaming the other in relation to some news he posted. He is adopting the strategy of asking a direct question, which is a strategy used by male speakers.

B. Wrongly predicted gendered comments:

1. / ?awæ:dim iljæ:bæ:n fi: kul Jei? (..) balad wfaSib jistahiq ilhajæ:t

(..) wlæ:zim nqaddir hæ:ða ifji:/

(Japan is different in everything...a country with its people

deserve life... we need to appreciate that)

The sentence does have dots between each sentence (part of repeating letters strategy), that's why it is assumed to be a female comment.

However it has been found that it is a male comment.

2. / ja\{ni: hæ:j wad3ba kæ:mla (?) lo: muqabbilæ:t qabl ilyada (?) !/

(I mean, is this the main course or starters before lunch?!)

The sentence contains a question with options for the answer. In addition, it involves the addition of / jaSni:/ (I mean) at the beginning. All these made us assume it's a female comment.

However it is a male comment.

3. / wæ:diћ ?innahum juri:du:n qatlahu (,) jimkin ilvidju: fi: ?afri:qja ilwusta/

Does Anonymity Matter? A Discoursal Study of Gender Recogniton on Arabic Facebook Comments 
(It's clear they wanted to kill him, $\underline{\text { I think }}$ this video is in middle

Africa)

Using the hedge / jimkin/ (I think) makes it look like a female comment. However, it is a male comment.

\section{Conclusions}

The study has come up with several conclusions which confirm the hypotheses raised. It has been found that females have more stock of words for colours than males. Besides, they use a smaller range of empty adjectives than males. Males use specific adjectives, viz. / hilwa/ (sweet), /d3ami:la/ (beautiful) especially when describing people. Some of the adjectives are restricted to females only, viz. /kju:t/ (cute), /ræ:?i؟a/ (elegant), /d3ami:I/ (handsome), /qadi:ra/ (good), and / ræ:qi:/ (elegant), though /hilwa/ (sweet), / Sazi:za/ ( precious) and /d3ami:la/ (beautiful) are used by both males and females.

Moreover, the cross-interaction between males and females also involves some empty adjectives. This can be shown through adjectives like: /mubdi؟/ ( creative), /mutamajjiz/ (distinct), /rahi:b/ (incredible), / adi:m/ (great), and /raw (amazing). In addition, the frequent use of intensifiers was shown to be used by females. Males usually use intensifiers with negative adjectives as /?istiGræ:di:/ (show off) commenting on other people whether these people are from their community or being regional, while females use it with positive adjective like /hilwu:/ (sweet) and /d3ami:I/ ( beautiful ). Besides, in female- female interaction, the intensifier /kullij/ (so) has been found more frequently.

Furthermore, hedges are frequently manipulated by females while vulgar words have been used by females less frequently in all the types of interactions (it is adopted just when interacting with another female). This is due to the fact they are judged by the society more than males. Besides, when vulgar words are used with another female, all that depends on how close their relationship is.

As for emphatic expressions, they have been used less frequently by males. This is due to the fact that females usually agree and support others' opinion. Some examples of the emphatic expressions include /ficlan/ "really " and /?e: walla/ ( I swear). The word /?aki:d/ (for sure (definitely)) was the only lexical item used by males as an emphatic expression.

Tag and direct questions have been realized with females' comments for the purpose of (in the case of tag questions) asking for affirmation, and (in the case of direct questions) not having courage to say what they want directly or for saving others' face by hiding what is required with a question.

Moreover, imperative has been more frequent with males in their interaction with other male friends than females. When using imperative, females either use it in a funny sarcastic way or they add some intimate words to let the order have a more polite and not harsh or direct effect on others.

Sarcasm has a high proportion with male same-sex interaction. Besides, females are found to be more concerned about others' faces that is why flaming has been manipulated less frequently by females than males and the number goes down

Does Anonymity Matter? A Discoursal Study of Gender Recogniton on Arabic Facebook Comments 
when females interact with other females. Females are also more open to criticize others indirectly.

In contrast to females who are more conservatives, males are more open and feel free to express their opinions on Facebook. As far as politeness is concerned, it is more common with females; they thank, apologize and show appreciation. In contrast, males appear to be less concerned with politeness, using criticism and tend to be more concerned about threatening the freedom of expression. Repetition of letters has been adopted extensively by females in contrast to males while exaggeration has scored the most frequent with females but interestingly little realization has been found in male- female interaction.

Depending on the finding, a test has been designed to find out whether or not applying the discoursal features discovered would let us recognize or predict the person's gender and identity through their comments on Facebook. Through the test, it has been discovered that females' comments (language) are more distinguished (prominent) than males'. The discoursal features that females use in their comments enable us to recognize their comments easier than that of males.

The wrong assumptions in the test were related to males' comments. That is, males can hide their gender with having some feminine language features (norms) such as using hedges which is a feature used more frequently by females. As a result, one may conclude that identifying or predicting the person's gender and identity out of the comments is not $100 \%$ accurate, though suggestive through the findings arrived at in this study.

\section{Recommendations}

The focus of gender differences over the past years has been on daily life conversation to the exclusion of the Internet. Hence, more studies can address this issue from a different perspective. Gender differences on the Internet can be added to the materials of the linguistic studies besides gender differences of everyday language.

The psychological gender differences in communication styles and influence tactics create stereotypical roles for males and females in conversation. These roles have implications for differences in, for instance leadership styles between males and females. Gender differences in Internet language will cause misunderstanding or pragmatic failure between males and females. This can be another topic for future studies. Moreover, social media programs have been realized in our life more than others; some of these programs are taking the place of Television like You Tube; the content of these videos plus the comments may be a perspective field.

\section{References}

Ahmad, S., Rafiq, M., \& Ahmad, S. (2018), Gender disparities in the use of internet among graduate students of a developing society. Global Knowledge, Memory and Communication, 67(4), 226-243.

Does Anonymity Matter? A Discoursal Study of Gender Recogniton on Arabic Facebook Comments 
Arize, E. (1996). Men and women in Interaction. New York, NY: Oxford University Press.

Berchmeir, Z., Dietz-Uhler, B. and Stasser, G. (Eds.) (2011). Strategic Uses of Social Technology: An Interactive Perspective of Social Psychology. New York: Cambridge University Press.

Crowston, K. and Kammerer, E. (2010). Communication Style and Gender Differences in Computer- Mediated Communication. Retrieved from https://crowston. syr.edu/content/communicative-style-and-gender-differences-computermediated-communications

Fischer, A. (2011). Gender in Face-to- Face Communication and CMC. In A. Nicole and Kramer C.: Face- to- Face Communication Over the Internet (pp. 53-79). New York: Cambridge Unversity.

Herring, S. (1995). Men's language on the Internet. (Proceedings of the 2nd Nordic Language and Gender Conference) Retrieved 2017, Aug 17 from http://ella.slis.indiana.edu/ herring/men.1995.pdf

Herring, S. (1996).Posting in a different voice: Gender and ethics in computermediated communication. In: C. Ess (Ed.): Philosophical Perspectives on Computer-Mediated Communication (pp.115-145). Albany: State University of New York Press.

Herring, S. (2000).Gender differences in CMC: Findings and implications. The CPSR Newsletter, 18(1)

Herring, S. (2003).Gender and Power in an Online Communication. In J. Holmes and Meyerhoff, M. (Eds.): The Handbook of Language and Gender (pp.202- 229). New York, NY: Blackwell Publishing.

Herring, S., \& Stoerger, S. (2013). Gender and anonymity in Computer-Mediated Communication. In J. Holmes, M. Meyerhoff, \& S. Ehrlich, (Eds.): Handbook of Language, Gender and Sexuality (2 ${ }^{\text {nd }}$ ed.) (pp. 567-586). NJ: WileyBlackwell Publishing.

Holmes, J. (2006). Gender Talk at Work. USA: Black Well Publishing.

Kapidzic, S. and Herring, S. (2011). Gender, Communication and Self- Presentation in Teen Chatrooms Revisited: Have Patterns Changed?. Journal of ComputerMediated Communication, 17(1), 39- 59.

Li, Q. (2005). Gender and CMC: A Review on Conflict and Harassment. Australasian Journal of Educational Technology, 21(3), 382- 406.

Li, N., \& Kirkup, G. (2018). Gender and cultural differences in Internet use: a study of China and the UK.Computers and Education, 48(2), 301-317.

Lin, X., \& Wang, X. (2019).Examining gender differences in people's informationsharing decisions on social networking sites. International Journal of Information Management, 50, 45-56.

Miller, J., \& Durndell, A. (2004). Gender, Language and Computer- Mediated Communication. In K. Morgan, Sancher, J. Brebbia, C. and Voiskounsky, A. (Eds.): Human Perspectives in the Internet Society: Culture, Psychology and Gender (pp. 235- 244). USA: WIT Press.

Does Anonymity Matter? A Discoursal Study of Gender Recogniton on Arabic Facebook Comments 
Mustafa, B., İrem, H., Kozan, Ö and Kesici, Ş (2018). Gender differences in and the relationships between social anxiety and problematic Internet use: Canonical analysis. The Journal of Medical Internet Research, 20(1).

Rollero, C., Daniele, A. and Tartaglia, S. (2019). Do men post and women view? The role of gender, personality and emotions in online social activity. Cyberpsychology: Journal of Psychosocial Research on Cyberspace, 13(1), 1

Sambasivan, N. (2019). Moving toward a gender equitable internet. Retrieved from https://www.blog.google/technology/next-billion-users/towards-genderequity-online

Savicki, V., Foster, D. and Kelley, M. (2006). Gender, Group Composition and Task Type in Virtual Teams. In M. Davidson \& Barrett, M. (Eds.): Gender and Communication Issues at Work (pp. 270- 282). Aldershot, UK: Ashgate Publishing.

Sussman, N. and Tyson, D. (2000). Sex and power: Gender differences in computermediated communication. Computers in Human Behaviour, 16(4), 381- 394.

Thomson, R. (2006). The Effects of Topic of Discussion on Gendered Language in Computer-Mediated Communication Discussion. Journal of Language and Social Psychology, 25(2), 167- 178.

Weatherall, A. (2005). Gender, Language and Discourse. New York: Taylor \& Francis.

Yates, S. (1997). Gender, identity and CMC. Journal of Computer Assisted Learning, 13 (4), 281- 290.

\section{Appendix}

Test of Recognizing Gender Anonymity

A. Truly predicted gendered comments:

1. / ?ild3æ:nib il?insæ:ni: mu: ma\{næ:ha jiftiyil ?ilak ibbalæ:J (.) jitৎab wjinfak halga biliqræ:ja 6 sni:n wxafæ:ræ:t wlaৎabæ:n nafis wbas mari:d jsi:r bi: ji: jikৎudu:n \aJæ:?irijjan wye:rha

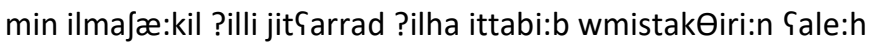
jæ:xið flu:s Sala ittaSab illi Jæ:fa/

(The humanitarian aspect it is not about working for free. After all these years of studying and hardworking and if something happens to the patient, instead of resorting to the law, they follow tribal ways and humiliate doctors; for all these reasons and you say doctors don't deserve the money they take!)

It's a male comment since he is again flaming the one who posted a statue against the doctor; the person, in reaction, is defending doctors.

2. / rabbi: jiћfadki ?ilnæ: jæ:warda ?inti: (..) habi:bi xals: (..) wnniSim minki:/

(God bless you ... my love my uncle .... Good for you)

It is assumed that it is a female comment. This is because the person left a space through dots between phrases, one of the ways of repeating letters strategy where females have been found to use it more frequently than males.

Does Anonymity Matter? A Discoursal Study of Gender Recogniton on Arabic Facebook Comments 
3. / lam jakun hæ:ða su?æ:I đu: ?ahammijja biqadar issabab waræ:?ahu ittahakkum Yala diju:fihi biYibæ:ræ:t samid3a muћæ:wilan ?ihæ:natahum (..) bira?ji: taSli:qæ:tihi hæ:ðihi wataqdi:m diju:fihi bihæ:ðihi ttari:qa huwa ?aqsa d3iddan min almawæ:qif issaxi:fa illi: jadaৎuhum fi:hæ: (...) hæ:kađa ra?eit/ (This was not an important question as much as the reason behind this taunt against his guests trying to humiliate them...in my opinion, his comments and the way he talks to his guests is harder than the situation he posts them in).

It is supposed that the comment is posted by a female. The person uses space between sentences, one way of repeating letters strategy; she also uses intensifiers /d3iddan/ (so) with the adjective /?aqsa/ (harder) which females use more frequently than males.

In this comment, one notices the use of /bira?ji:/ (in my opinion) and /hæ:kađa ra?eit/ (I think); these are part of hedges strategy which females usually adopt in order not to impose their opinion on others.

4. / hæ:ða ћariq mu: (?)/

(This is burn, isn't it?)

Here a tag question is adopted then it is a female comment.

5. / lahd3itak kulli[ hulwa kul il?iћtiræ:m wattaqdi:r ilhadirtak (,) ?insæ:n tajiib wmuӨaqqaf wmuhtaram wmutawæ:dis basi:t li?abSad ilhudu:d rabbi: rabbi: jihfadah/

(Your dialect is so beautiful, all the respect for you, you are kind, educated, respectful, humble and simple, God bless you)

The person uses the word / kullif/ (so) as an intensifier. The person also uses more than one empty adjective. Then the comment is definitely posted by a female.

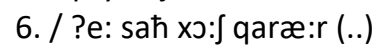

ja؟ni: ittullæ:b illi mæ:ku ilqisim bmuћæ:fadæ:thum jikdaru:n

hassa jhaslu:n makæ:n bil?aqsæ:m/

(That is a good decision, I mean there will be a space in the

dorm for those who attended departments not in their cities)

In this extract, it is so clear the use of dots between the sentences (part of repeating letters strategy) as well as using hedges /ja؟ni:/ (I mean) then the person is surely a female.

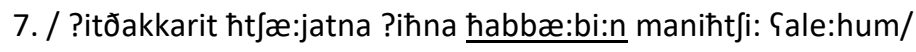

( I remember our talk, we are lovely people, we don't gossip about them )

It is assumed that a female is commenting since she is using the empty adjective /habbæ:bi:n/ (lovely), though she is using the words about herself and her friends but females in general use this word more frequently than males.

8. / ?e: walla læ:nigdar niqra qabl ilftu:r wlæ: baৎda/

(Yes, right (I swear), we can't read before or after Iftar)

Using affirmative expression /?e: walla/ (I swear ) showing agreement with the statues being posted, it is an outstanding feature of females' posts. So, it is a female comment.

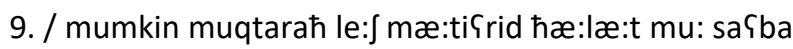
wmuৎaqqada min wæ:qiৎ ilhajæ:t ilৎamalijja mu: ?amræ:d

Does Anonymity Matter? A Discoursal Study of Gender Recogniton on Arabic Facebook Comments 
næ:dira wyari:ba (..) winta ?aৎlam ?aki:d/

(May I suggest something, why don't you post common cases

instead of rare ones and diseases? And for sure you know

better)

The person is requesting to present a suggestion, where he adds at the end /winta ?aSlam/ (up to you ) leaving the options open for the other; besides using affirmative /?aki:d/ (for sure). Then it's a female comment

10. / kul niৎil ?awwal sana twassalit bi:hum maqiblu:ni bæ:bil hassa tri:dni ?ard3aSilhum/

(Shut up, I begged them at Babil to accept me but they didn't, you want me to go back now)

The sentence has a cursing expression / kul nicil/, it is used between males which literary means (eat shoes) or we can say (shut up), then it's a male comment.

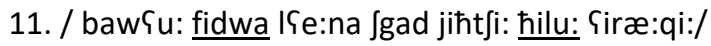

(Look how precious he is, he is talking with a nice Iraqi accent)

Using an intimate word which females say it more frequently /fidwa/ and an empty adjective /hilu:/ (sweet), then it is a female post.

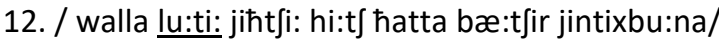

(He is such a deceitful person, talking like this to persuade people to vote for him)

Using the word /lu:ti:/ (deceitful) which is a cursing word plus it is flaming but not against the person directly then we expect it's a male comment.

13. /?awe:li: Yale:hum xattijja ?alla jsæ:Yidhum/

(I feel sorry for them, may Allah help them)

Since females are more supportive and concerned, they show their feelings and sympathy through their comments more than males. It's a female comment.

14. / d3ami:I d3iddan ?atðakkara bil؟urus mæ:I ؟ammi: ?alla jriћma

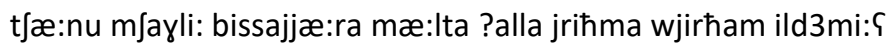
jæ:rab/

(This is so beautiful, I remember this was in my uncle's

wedding; they played it in the car, May God have mercy on him).

The use of the intensifier /d3iddan/ (so) with the adjective /d3ami:l/ (beautiful) as well as kinship term / Sammi:/ (my uncle), then it is a female comment.

15. / wintu: Өawrutkun ilfikrijja maৎam tiqdar titd3æ:waz iddi:n

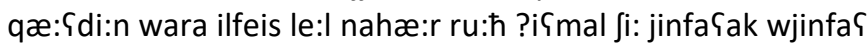
ilnæ:s mu: ?aћsan min halhat $\int i: /$

(What about your intellectual revolution, you are just talking about religion, sitting behind your laptops all the time without doing anything to help others).

The sentence is a direct flame, blaming others which is more of a male style.

16. / walla hijja kæ:lat ?illi ?ari:d ?aku:la halqa sajji?a fiৎlan/

(Yes I swear, she said what I wanted to say, the episode was really bad).

The person uses an affirmative expression /walla/ (yes, I swear), also using an empty adjective /ficlan/ (really) which make us assume that it's a female comment.

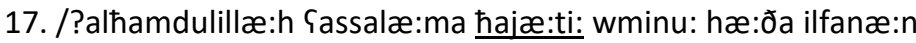
wlæ:suyran bi: (?)/

(Thanks God you are safe my life, can I ask who is this actor if you don't mind?)

Does Anonymity Matter? A Discoursal Study of Gender Recogniton on Arabic Facebook Comments 
The person uses /hajæ:ti:/ (my life), an intimate word used more frequently by females. The person also uses a request to ask about an actor. Then it is a female comment.

18. / ?inti: ¡ððっ:q kulla jæ:rayyu:da saћ ilsæ:nik habi:bti:/

(You are very respectful Raghooda and you are right $\underline{\text { my love })}$

The person here is complimenting a girl, using the intimate word

/habi:bti:/ (my love) which is used by females with nickname for the girl as well, so it is a female comment.

19. / ?iðan fassir li: keifa nufarriq beina Imalmas innæ:Sim walxajin walmudabbab wayeiruhu/

(Explain for me how can we distinguish between a soft and rough surface)

In the previous sentence an imperative is used which reflects that it a male comment.

20. / Jwakit tiftahu:n fariৎ bibaydæ:d (?)/

(When will you open a branch in Baghdad?)

A direct question is used more frequently by males. Thus, it is a male comment.

21. / ?udxul Sarræ:bit ilfo:g Ju:f ?ixtisæ:sak mawd3u:d/

(Check the link above and see if your specialization is there)

The sentence has an imperative structure, then it is a male comment.

\section{B. Wrongly predicted gendered comments:}

1. / rad3æ:?an bas ?ari:d ?aSruf ?iðæ: ittaqdi:m baSid maftu:ћ (?)/

(Please, I just want to know if application is still available?)

The sentence contains a request form as well as the use of the word

/rad3æ:?an/ (please), then it should be a female comment. However it was against our assumption.

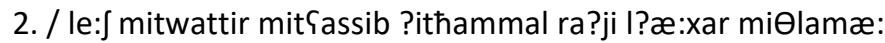

jiłtirimak/

(Why you are nervous, respect other's opinion just as they respect yours).

The sentence contains a direct question with flaming the person replying to through using an imperative structure. This assumes that it is the style of a male comment. However, it was posted by a female person. 